\title{
Religious Correctness or Homophobia: Cross-Examining the Identity of Gay Muslims in Germany
}

\author{
PATRICK AGBEDEJOBI \\ pnagbedejobi@uclan.ac.uk \\ University of Central Lancashire
}

\begin{abstract}
This article offers new ways of identifying and perceiving gay Muslims in Germany through discursive practices, such as the acceptance of queer Muslims in Islam, alongside cultural hegemony of religious gatekeepers. The article specifically explores the utilisation of Norman Fairclough's (2010) critical discourse analysis to comprehend the identity of gay Muslims in Germany and to advance the current understanding of gay Muslims and their relations within the socio-religious space. The nature of this relationship is demonstrated through discursive choices (the identity of gay Muslims within a religious context and in society); the use of dominant and restrictive subjective narratives and language between group gatekeepers (religious leaders: Imam and Islamic devouts); and the isolated members of Islam (gay Muslims). This enquiry will be illuminated by qualitative critical discourse analysis interviews on YouTube in which specific actors related to the study were interviewed on themes such as identity, acceptance of gay Muslims and relations with them in a religious community or a social space.
\end{abstract}

\section{Introduction}

Fatima El-Tayeb's (2012) article, Gays Who Cannot Properly Be Gay: Queer Muslims in the Neoliberal European City, resounds the thematic discourse and intersectionality involved in framing a homogenous class of gay Muslims (GMs) as a class with no cultural roots in Islam or in Western ideology. As an isolated class, GMs are labelled as incompatible with Islam and its teachings (Appendix: Extract 1.1 and Extract 1.3) and, in this way, a GM is considered 'haram' (forbidden) and non-existent. Therefore, engaging in a discourse about GMs is forbidden or met with condemnation from a conservative perspective (El-Tayeb, 2012; Ganzevoort et al., 2011).

However, a liberal faction of Islam that accepts GMs does exist. This acceptance is dependent on a minority call for reform to Islamic teachings and dogmas; hypersexualisation of GMs, the post-migration aftermath of Arab hybridisation and a European-oriented Islamic theology grounded in liberalisation and respect for human right norms (Noble and Tabar, 2002; Ewing, 2008; Partridge, 2012: 163-170; Rehman and Polymenopolou, 2013; Houben, 2015; Das erste Mediathek, 2018; Tagesschau, 2018b). As an aftermath, this European liberal view of GMs antagonises rigid religious dogmas and evokes an investigation into the way in which religious correctness affects GM's identity in Germany. 
Consequently, GM relations and discourses emerge; often within the context of multiple stereotypes and interpretations reinforced by the other. This is based on antagonistic, nonintersectional, cultural, socio-religious construction of identities and spaces (El-Tayeb, 2012; Akachar, 2015). The institutional reproduction and sustenance of homogenous sexuality and its othering is an interplay of power, sexuality and status, language/dialectics of discourse, hegemony, politics, and dialectical relations between Western ideas and the other (Akachar, 2015; Hegarty, 2019).

In order to unravel the framing of GMs in Germany, the following article embarks on an analytical investigation that questions: How does religious correctness (RC) affect the construction of identity of gay Muslims in Germany? In order to comprehend the milieu within which GMs are framed or constructed, an introduction to related concepts is crucial.

The concept of religious correctness (RC) is introduced to the study as a political and sociocultural construct. In the parlance of political science, RC can be identified as a subject of securitisation - that is, the intentional act or speech act by power wielders that gives birth to the use of a certain concept with a specific meaning in a public sphere (Eroukhmanoff, 2018). In this way, the securitising actor progresses from a platform of dominance and power to initiate, objectify, classify or give meaning to societal events or constructs. In the Islamic religious community, GM's perception emanates from this perspective of dominance, which is enforced by gatekeepers and masculinity.

In order to expand the discussion on RC, a brief examination of political correctness (PC) is crucial. PC is a political controversy in which both those who are labelled 'PC 'and those who label them 'PC' are engaged in politics focused on representations, values and identities (Koopmans, 2004; Fairclough, 2010). In this way, PC can be regarded as cultural politics applied in discriminating or laying a social marker of difference between a group and the dominant group. Therefore, when immigrants are targeted by speech acts, they are represented or framed in either a positive or a negative perspective. As such, the subject of dominance and hegemony is reiterated in both RC and PC as an analytical tool explaining societal issues in terms of agency-based relations.

This article positions $\mathrm{RC}$ as an institutionalised arm of cultural politics within religious or socio-political circles, which determines the 'who', 'when' and 'where' the power of construction and representation - particularly language (homogenous interpretations of sacred texts), socio-political change and legitimacy of actions - resides (Koopmans, 2004; Akachar, 2015; Jones, 2016; McLellan, 2017). Therefore, RC engenders social history and cultural change in the socio-historical context of the RC controversy. I argue that the process of othering of GM within the Islamic community is a function of RC or patriarchal domination of religious gatekeepers and cultural hegemony. In what follows, I initially contextualise GMs from a European position within the available literature. The contextualisation is followed by an exploration of the methodology which involved Norman Fairclough's (2010) critical discourse analysis (CDA) approach, to examine and disclose the framing of GMs in Germany through the analysis of content acquired through a YouTube search. 


\section{Theoretical framework: cultural hegemony and gay Muslims}

As a point of entry, it is crucial to locate GMs within existing literature. GMs are generally defined in terms of homosexuality, which implies attraction to same sex or gender. Zulkffli and Ab Rashid (2019: 309-310) posit the Islamic position towards homosexuality, which is premised on the Quran's narrative of Lot's actions in the community filled with gay transgressors in Hadith 3577. This is further evidenced by the submission in the Quran (Surah Al-A'raf 7:81). Zulkffli and Ab Rashid (2016) opine that, although Islam condemns the sexual acts of homosexuality and perceive homosexuality as sinful, it does emphasise with the person struggling with such a transgression (Zulkffli and Ab Rashid, 2016). These transgressions are said to arise from emotive acts of lust or desire - a perspective that contradicts the biological or psychological evidence supporting the fact that GMs' emotions are not based on lust for same sex intercourse or relationships.

Furthermore, El-Tayeb (2012: 81-84) portrays GMs or the "class in itself" as a product of European construction - a construction shaped by hybridisation fostered by second and third generation Muslims from Arab descent, or by parents involved in the unforeseen consequences of the 'guest worker scheme' (Gastarbeiter Programm) in the 1960s. The guest workers, who decided to remain in Europe, created a multicultural class subject to antagonistic policies and media debates (Miller, 2018). Socioeconomic marginalisation remains unaddressed in several European cities, with Muslims in general being depicted in media and daily lives as incompatible with European values and laws. This antagonistic relation is also evident in discourses on terrorism or radicalisation, such as the hijab debates, which position European Muslims as the other or in the context of the European refugee crisis that commenced in 2015 (El-Tayeb, 2012: 81-82; Agbedejobi, 2017; Mechoulan, 2018; Miller, 2018).

The 'otherness' and competitive isolationism of GMs in the religious community warrant detailed analysis. In other words, in order to answer the main question posed by this article (i.e., How does religious correctness (RC) affect the identity of gay Muslims?), I argue that RC and homophobia displayed by dominant gatekeepers and devout followers of Islam may effectively be conceptualised as a function of cultural hegemony.

Cultural hegemony comprehends culture in relation to RC as a form of dominance, which produces a dual tool that is utilised as either a resource or a restraint (Lears, 1985; Forgacs, 1988). Therefore, power and control over subjects are based on self-reinforced institutional resource reproduction through cultural text or control of social practices and relations (in this case, through RC or a sacred text) and physical force (corrective gay therapy, alienation of GMs or otherwise).

The study situates RC discourse as a particularly significant resource used by dominant social forces to direct and control the course of major social and cultural changes that affect contemporary societies. Moreover, control over discursive practices is understood as one dimension of cultural hegemony. The other dimension is restraint, in which the status quo is maintained by restructuring hegemonies based on strategic calculations of the wider hegemonic and ideological effects of discursive practices and a strict adherence to rules and cultural practices.

Understanding the framing of GMs in Germany requires a theory of power, class and state in modern liberal capitalist societies capable of explaining structural relations, complex group relations, interests, ideologies and a discourse of class (Forgacs, 1988). Therefore, adopting 
cultural hegemony for this article simply elucidates how concepts such as power, accepted social norms and religious institutions determine or constrain identity.

From a Gramscian philosophical perspective, political power of the dominant class in societies controlled by cultural hegemony is based on a combination of domination, control over the force of repression, the capacity to use force or declare punishment or reward, as well as intellectual and moral leadership (Forgacs, 1988). This hegemonic control as depicted by Gramsci overstretches its reach to the domination of the institutions of civil society (family, work, education, religion, leisure, etc.) (Fairclough, 2010: 128).

Positioning research on GMs within 'a class-in-itself-Muslims' results in a discourse on relations with the other, thereby constituting a dual relationship of discourse to hegemony. On the one hand, hegemonic practice and hegemonic struggles or controversies take the shape of discursive practice, both in spoken and written interactions (Lears, 1985; Fairclough, 2010). The set of discourse and conventions that are involved here are: the framing of Muslims in Europe among the existence of GMs, or the anti-Islam rhetoric utilised by right wing political parties that foster hate speech, and discrimination against any class closely related to Islam. On the other hand, discourse itself is a sphere of cultural hegemony, superstructure and the hegemony of a group or class over the entire society or sections of society, which, in part, points to its capacity to shape discursive practices or the orders and turns of such discourse (Forgacs, 1988). In this way, GMs are labelled as haram by Islam and its followers (homophobic strain), while gay rights are promoted in a liberal modern capitalist society (Tagesschau, 2018b).

The hegemony of a class or a group over an order of discourse is a function of an unstable equilibrium between its constitutive discursive practices, which may become unbalanced and open to restructuring in hegemonic struggles. For instance, in conservative Islam parlance, the Imam occupies different roles from which discursive relations and power relations emerge. The Imam is seen as a counsellor, guide, representative of Allah, patriarchal figure, dominating force and sole interpreter of sacred texts among many other roles. Within this context, the Imam or religious leaders assume a position of moral watchdogs. In addition, they sustain the hegemonic construct of social order, which is responsible for counter-hegemony reproduction, which, in turn, aligns with sacred text or idiosyncratic needs.

\section{Research approach}

Effective operationalisation of GM within the larger discourse of cultural hegemony requires a focused theoretical attention. For the purposes of this study, it is also critical to contextualise the process of continuous creation and reproduction of counter-hegemonies to sustain a worldview of dominance that isolates GMs. Furthermore, the use of language in communication and discursive practices and the way in which this influences identity framing and social markers should also be explored and understood.

As such, this article adopts a qualitative analytical approach, in order to depict, interpret and critically explain the ways through which discourses construct, sustain and legitimise social inequalities. Critical Discourse Analysis (CDA) is applied, in order to reach an understanding of the use of language in discourse, the identification of the social order and social wrongs related to GM identity. Because CDA focuses on social problems - not on scholarly paradigms 
- it can be applied to understand and address problems by means of any theory or methodology (Mullet, 2018).

\section{Data collection}

The first step involved in CDA is to identify and select a discourse related to social injustice or inequality. The unit of analysis may be an entire text or smaller units, such as paragraphs, sections and extracts. In this study, the discourse was identified by conducting a YouTube search with the following keywords: gay Muslims in Germany and attitude towards GMs in Germany. The rationale for the search is based on the analytical scope of this article, which involves an enquiry into identity and power relations of GM in Germany.

The YouTube search generated several results, which did not fall within the geographical or analytical scope of the article. After an objective scrutiny of the content dealing with the thematic issues of the article (i.e., perception of GMs in Islam, RC and gatekeepers' safeguarding, the reproduction of cultural hegemonies, patriarchy and sexuality), the search results were narrowed down to only three videos. In other words, the process of elimination which was followed was based on the occurrence of the thematic issues in the content of the videos. The following three videos, which are interviews on Tageschau (Daily News), conducted by a German journalist, were selected and used as primary data sources: (i) Moscheerport: Islam and Homosexualität (Mosque Report: Islam and homosexuality); (ii) Der Moscheerport: die Dar-es-Salam Moschee (Mosque Report: the Dar-es-Salam Mosque); and (iii) Der Moscheerport: Islam und Frauen (Mosque Report: Islam and women). The questions posed in these interviews align with the research scope and essential themes of this article (i.e., gatekeepers' perceptions of GMs in Islam and the construction of GM identities). The interviews required transcription and translation from German to English. ${ }^{1}$

\section{Data analysis}

In order to analyse the collected primary data, this study employs Critical Discourse Analysis (CDA), which is a creation of realist social ontology that perceives both concrete social events and abstract social structures as part of social reality (Fairclough, 2010: 73). The relationship between social events and social structure is mediated by social practices, which, in turn, determine the selective actualisation of semiotic dimensions. The selective actualisation of such semiotic dimensions is explored through a process of abstraction. For instance, social structures produce a level of abstraction that can be understood through language, while social practices indicate the order of discourses and social events point to the comprehension of text. Texts - whether written or spoken - are the building blocks of discourse that provide insight into language, which, in turn, is an essential part of social life and also provides description of structures, social practices and relations among people and among institutions and people. In this way, language provides insight into discourse (Waller, 2006). Discourse creates an image of a particular reality and reflects the way in which meaning is constructed in certain situations (Waller, 2006).

\footnotetext{
${ }^{1}$ Excerpts of the interviews are available in the Appendix.
} 
Like Discourse Analysis (DA), CDA examines the way in which language produces psychological and social phenomena (Mullet, 2018), with the difference being the fact the CDA focuses on the role of language as a power resource. CDA is mainly based on the assumption that institutions act as gatekeepers to power, discourse resources, unequal access to those resources, as well as imbalances between speakers and listeners. As Mullet (2018) further observes, CDA primarily deals with the discourse of power abuse and injustice and, therefore, it attempts to uncover power relations and the linguistic manifestations of power (e.g. prejudice and oppression being reproduced in daily life by political and media discourses controlled by elite groups).

This article aims to explore the CDA methodology adapted from Fairclough (2010: 235), which comprises of the following four stages:

1) focus on a social wrong in its semiotic aspect.

2) identifying obstacles to addressing the social wrong.

3) considering whether the social order 'needs' the social wrong.

4) identifying possible ways past the obstacles.

\subsection{The application of Fairclough's CDA in the context of GMs in Germany}

\subsubsection{Stage 1: Social wrong in its semiotic aspect}

In the context of this article, the social wrong refers to injustices or inequalities that people encounter in society. In existing literature, the identity of GMs occurs within the intracategorical/intersectional element of ethnicity construction, labelling and othering in terms of being Arab, Muslim, Islamophobia, terrorism and radicalisation (El-Tayeb, 2012: 81-82; Mechoulan, 2018; Miller, 2018; Zulkffli and Ab Rashid, 2019).

The first social wrong stems from the construction of classes, gender specification and roles, ethnicity, as well as social stratification. It is argued that, although social stratification predates globalisation, it has more than often been a barrier to social cooperation and peace. Therefore, the concept of being Arab or being labelled as Arab - particularly in Western parlance - has been stigmatised and securitised over the past decade. In the context of Stage 1 in Fairclough's (2010) methodology, the social wrong is the concept of being Arab.

Aly (2015) posits that 'Arab' is a contested construct with multiple sub-structures. The reason for this may be that the concept of being Arab is used to depict a homogenous ethnic group fragmented by differences in language, class, nationality, status, education, socio-history, culture and geopolitical factors, which themselves are used to determine whether a group member is either an ingroup or an outgroup member. According to Aly (2015), being Arab itself is fluid, as some characteristics of being Arab may be present in some cases and not in others, resulting in hybridised Arab identities. A good example is second or third generation Europeans born and raised in Europe by immigrant parents with ancestral lineage to the Middle East, North Africa or Persia. This group of Europeans cannot speak Arabic or the native language of their parents. However, even without any concrete connection to the Arab world, these people are labelled as being Arab, instead of European. Conversely, even those who do speak the Arab language, or who regularly visit the home countries of their parents may still not identify as an Arab. 
Other issues that surround this categorisation include issues of sectarian variation, variation in religious practices or the homogenous media narrative which labels all people from Arab countries as Muslims. In terms of sectarian variation, Muslims are divided into Sunni and Shi' ite Muslims, with differing ideologies or theological orientations. More so, there are people within the label categories who are atheist or agnostic or who convert to other religions, which clearly makes the entire labelling and categorisation incorrect and irrelevant.

The argument is further supported by distinct generational ideology, which accounts for differences in attitude, nationality and citizenship experienced in generational shifts. The term 'hybridised Arab identity' - which refers to generations born in Europe without any concrete pull or push towards the birth countries of their parents - is relevant in this case. In such situations, parents are most notably still in observance of customs, culture and religious rituals of their homelands, which are mostly patriarchal, stress obedience, and rigidly follow conventions and gender roles (Hermans, 2006). As established by Shaheem (2014), those with a hybridised Arab identity are liberal minded and embrace the cultural perspective of their birth countries. Therefore, their behaviours, value systems and/or beliefs tend to be fluid, embracing major elements of Western culture and celebrating some Arab cultural practices. This is denoted as flexible hybridity, where no single culture or group influences the daily lives or idiosyncracy of the subject (Noble and Tabar, 2002: 141; Hegarty, 2019).

In a nutshell, being Arab or from Arab descent comprises a fluid construct, both from the perspective of the giver of meaning or from those with such identity. However, the former has power or social control in terms of determining the meaning of being Arab. This is evidenced in the modern-day usage of being Arab or Muslim in public discourse.

Critical race theory approves of this framing of the other, in that it asserts that racism is deeply entrenched in social life, from both the institutional and structural actors (Delgado, 2001). This goes further to support the view that public discourse is a presentation of social reality that is always construed against the other. This bitter narrative serves as an element or a tool of domination in terms of how interpretive structures are sustained and the worldview it reifies.

The dialectical-relational approach of CDA, which requires a semiotic point of entry in explaining RC, homophobia and Western domination, lies within these theoretical frames. To this end, the article seeks to analyse the impact of RC and homophobia and how such effects frames social interactions with GMs in Germany. As such, the material of Tagesschau (2018a) will be analysed as a semiotic point of analysis.

\subsubsection{Semiotic analysis}

A transcription and German-to-English translation of the video content are available in the Appendix. In this case, the respondents (interviewees) were: Ibrahim, an asylum seeker from Lebanon, currently based in Cologne, Germany; Ahmad Mansour, Psychologist; Adnan Aslan, Professor of Islamic studies at the University of Vienna, Austria; and Said Ahmad Arif, Imam at the Khadija Mosque in Berlin, Germany.

According to Eco (1976: 25), semiotic analysis is based on a dialectic between acceptance and repudiation of the sender's code or the introduction and rejection of personal codes. In this way, text or visual messages provide meaning and reason for differentiated explanations of discourse. Van Leeuwen and Jewit (2001) also posit that images can be understood without 
any alternative to verbal or written information that may follow them. Therefore, the semiotic analysis undertaken in this article relates to comprehending GMs isolated space within the context of what is written, said or done through gestures.

As such, the visual report and the questions posed by the interviewer to respondents produced a dialectical relation with the social wrong that informs the semiotic analysis. The semiotic analysis is coded in the following four thematic frames originating from the visual source, namely: sexuality and masculinity, isolationism of GMs in Islam, RC and gatekeepers and Islam and homosexuality.

\subsection{Thematic frame 1: sexuality and masculinity}

In the discourse between GMs and their acceptance or non-acceptance in Islam, the issue of sexuality and masculinity is overshadowed by rigid, patriarchal and normative contexts of homogenous sexual orientation. This implies that the traditional status quo of a man marrying a woman is an unshakeable precedent that moves from one generation to another. The relational construction of sexuality and Muslim masculinities position men as chief beneficiaries of a profoundly patriarchal, mandatory heterosexual status quo, and sustained cultural practices that dictate the behavioural expectations of community members.

As reiterated by the submissions emanating from how gay men are perceived in Islam, the interview disclosed the following:

[...] When you are gay, you bring shame to your family and community. They do think they have failed as a parent in terms of your upbringing. Second point is building your case against the divine (Allah) (Appendix Extract 1).

Therefore, sexuality and masculinity are constructs of social and religious relations and group norms. The interconnectedness of each community member with the norms and practices also makes it extremely difficult to separate private from public life. This is informed by the role of agency and cultural pathologisation in the institution of family and RC.

\subsection{Thematic frame 2: Isolationism of GMs in Islam}

As an aftermath of the rigidity of the rules of social and religious relations within a closely interconnected group, GMs are subject to isolationism or rebuke. As signified by discursive practices within the German Islamic community, their existence is mostly depicted as a taboo, forbidden or outcast, silenced or supressed sexuality, nicht haram, disgrace or shame, among other labels (Appendix: Extract 1, Extract 1.1, and Extract 1.2).

\subsection{Thematic frame 3: RC and gatekeepers}

$\mathrm{RC}$ emanates from a position of power, authority and dominance. As such, cultural practices interwoven with religious norms create a conducive medium through which certain practices are sustained. RC is further entrenched in the discourse of GMs masculinity as a false revolt against the accepted norm of sexuality and sexual orientations. A principal-agency problem, therefore, erupts with the dominance of gatekeepers alongside their followers overwhelming 
any support that GMs might have acquired. In other words, the institution of gatekeeping is not exclusively restricted to religious leaders: rather, the influence of RC allows for a decentralised scope of safeguarding cultural practices and norms through masculinity. Therefore, when attacks are launched against GM in the public or private sphere, the gatekeeping role of any believer is activated (Appendix: Extract 1.1.1, Extract 1.2.2, and Extract 2.1).

\subsection{Thematic frame 4: Islam and homosexuality}

The trade-off between RC and patriarchal dominance paves the way for a sustained homophobia towards GM in the Islamic community in Germany. According to excerpts from the interviews, the forbidden nature of homosexuality emphasises the ubiquity of RC and institutional stickiness (Appendix: Extract 2.1, Extract 2.2, Extract 2.3, and Extract 2.4). As the superordinate unit of social institutions, the family is a construct (Abdel-Raheem, 2019: 6-9). It is an age-old practice or convention that stipulates that a man and woman symbolise the constitution of a family. The modern-day challenge of such institution is seen in the growing increase of cohabitation, polyamory and homosexuality among other forms of modern relationships. Thus, the position of Islam about homosexuality despite its conservative leaning is continually challenged and may generate a feedback loop. This feedback loop, however, is a function of the predominant characteristics of an era and how liberal the Islamic community becomes. This is evinced by Extract 2.4 (Appendix).

\footnotetext{
English: Was this always so in the Muslim community? Or was there a time when homosexuality was accepted?

MM German response: In Muslimische mittelalter, hat sich eine Kultur der Duldung. Duldung als Unterstufe der Toleranz heraus entwickelt. Man hat homosexualität geduldet so lange sie eben die homosexualität nicht in der öfffentliche raum presentiert oder rein transportiert haben. Sondern eben verborgene zuhause in Private ausgelebt habe. Es war eine Kultur ,'dont ask dont tell'.2 (Appendix: Extract 2.4).
}

\subsubsection{Stage 2: Obstacles to addressing the social wrong}

The human capacity of subjective or objective social stratification remains constant, even in the present day. Social stratification or the creation of classes or groups based on certain variables extends to the specification of gender roles. In other words, the obstacle highlighted in Stage two of the CDA approach is the construction of Islam masculinities.

Inhorn (2012: 6, emphasis in the original) depicts masculinity in four ways: "[...] as anything men think and $d o ;[\ldots]$ anything men think and do to be men; [...] some men being inherently more manly than others; $[. .$.$] as anything that women are not", reiterating gender relations.$

According to Inhorn (2012), these four ways of perceiving men are termed 'hegemonic masculinity', which fosters relationality or relationships between both societally prescribed genders (men and women). Hegemonic masculinity reflects general patterns of command over

\footnotetext{
${ }^{2}$ Trans.: "In Medieval Muslim era, there was a culture of tolerance. Tolerance developed at an elementary level. Homosexuality was tolerated so long as it remains hidden from public sphere. It was suppressed in public sphere, only allowed within private lives. It was a culture of 'don't ask don't tell'".
} 
resources, physical strength, heterosexuality and emotional detachment. Hegemonic masculinity is of relevance to the social wrong of being labelled as Arab, because it reinforces the intersectionality within other forms of masculinity. This is represented by the status quo that non-white, gay men are supressed and marginalised in the masculine hierarchy.

From the perspective of Muslim communities, in direct reference to Western context, hegemonic masculinity is premised on the divergence with opposite concepts, such as women and men who are deemed effeminate or something in between (De Sondhy, 2014; Tagesschau, 2018a; Abdel-Raheem, 2019: 6-9). It places greater emphasis on marriage, family and procreation. Therefore, any male who does not fit the requirements of hegemonic masculinity from a religious perspective, is an outcast; a homosexual whose lifestyle contravenes the requirement of the Islamic community (Siraj, 2010; Tagesschau, 2018a).

In addition, hegemonic Islamic masculinity demands the ideal Muslim man to be circumcised, to eat certain prescribed meat (Halal), complete military service and be ready to defend the country and Islam against any external or internal uprising. The latter part depicts the rationale behind the framing of Muslims by the media as terrorists or, as in certain closed communities within Germany, as a group prone to Jihadi uprisings or the establishment of Sharia law (Ganzevoort et al., 2011; El-Tayeb, 2012; Inhorn, 2012; Tagesschau, 2018a).

Subsequently, hegemonic Islamic masculinity is fostered by patriarchy. It subscribes to the construct that men are the only breadwinners of the family, as well as the decision-makers and role models (Hermans, 2006; Siraj, 2010; De Sondhy, 2014). As an ideology of male superiority and power, patriarchy is a major characteristic of Islamic masculinity (Inhorn, 2012), which informs the socialisation process of young Muslims maintaining and sustaining their belief and value system from childhood to adulthood. Therefore, the male role of dominance is entrenched through cultural, communal and religious practices. This role determines what gender gets educated and socialises. Rewards and punishment for complying or deviance, or what profession or clothing preferences to choose, are accepted by cultural norms and conventions.

According to Kugle (2010), this patriarchal hegemonic masculinity-based traits or features reinforce the societal construct of women as inferior or subservient to men. In this way, traditional gender roles empower and characterise men as heroes or role models. It also stipulates what is permissible or how members of a particular gender conduct themselves in the public sphere. In most cases, the female role is that of the victimised. Cases of honour killings in Pakistan, India and elsewhere suggest the power of hegemonic Islamic masculinity, which simply situates the patriarchal order and dominance in the public sphere. Honour is cited as preserving cultural practices or conservative gender-based roles. Any deviation from the norm is usually what leads to a retaliation or punishment of some sort, carried out by the masculine upholders of such cultural practices (Allie and Eran, 2016; Mayeda and Vijaykumar, 2016).

Consequently, hegemonic Islamic masculinity considers the female role as one of subservience. One in which the woman is a property of her husband (De Sondhy, 2012; Inhorn, 2012; Mayeda and Vijaykumar, 2016; Hegarty, 2019). As such, the traditional female role is one confined to domestic housekeeping or child rearing and upbringing. Over the past centuries, these conservative practices have reproduced hegemonies and counter-hegemonies, with feminist uprisings leading to partial consolidation of women's rights in the Middle East or 
Arab world, where the roles attached to women are still highly restricted. However, some minor changes - albeit only small numbers and still restrictive - have been witnessed that do reflect a certain extent of progress, e.g. women being allowed to drive in Saudi Arabia (BBC News, 2018). However, reflecting on the female gender role compared to that of GMs, highlights a crucial point: one of dominance by hegemonic masculinity (the fixed gender role of men) in which GMs are depicted as not being real men or not befitting the social construct of the family as an institution.

In research and scholarly work, the entrenchment of hegemonic masculinity has been subject to criticism. It is depicted as static, exclusive and homogenous (Garlick, 2016: 33-35). It is characterised as overlooking inconsistencies in the production of masculinities and the existence of multiple hegemonic masculinities (Garlick, 2016: 35). Therefore, like the label 'Arab', hegemonic masculinities should be considered as plural, diverse, specific to a group's culture, or historically and socially constructed.

In reaction to the diverse and peculiar nature of hegemonic masculinity, Inhorn (2012) observes that there are liberal and emergent masculinities that are different from the conservative or tradition-based hegemonic masculinity and these masculinities help in redefining masculinity. What is of critical importance is the way in which this redefined, alternative hegemonic masculinity relates to GMs and the interaction between GMs and the Islamic community.

According to Inhorn (2012), greater acceptance and differences related to LGBT rights in the Western community are evidenced by the existence of hybridised Arabs and conservative Muslims, which generates a robust discourse on the stark contrast in value systems and daily practices. For instance, the generation of hybridised Arabs is most likely more oriented towards Western values than the conservative Muslims, who strictly abide by the tenets of Islam or RC. As opposed to conservative Muslims, the hybridised generation engages in discourses that reshape the role of hegemonic masculinity (Connell and Messerschmidt, 2005; Jewkes and Morrell, 2012). Therefore, it can be inferred that affinity with Western values and the socialisation process is responsible for the generational shift, although caution should be exercised, as not all hybridised generation behaviour or value systems solely conform to Western ideology or practices. In terms of theological strategies of counter-hegemonies, GMfriendly mosques in Berlin and Munich (Ibn Rusd-Goethe Mosque or München - Schwules Kommunukations-und Kulturzentrum München e.V) create a public sphere secluded from the mainstream Mosques and theological position. In other words, hegemonic masculinity as it relates to GMs reiterate the dominance of mainstream or conservative Islam in shaping hegemonies based on masculinity perceptions or the requirements of procreation, family and marriage, among others. These requirements unreservedly exclude GMs from the Islamic community and any debates regarding to including them in the Muslim community are met by a hegemonic, masculine-based gatekeeping denial (Tagesschau, 2018a).

\subsubsection{Stage 3: Does the social order need the social wrong?}

At this stage, the social order that fosters discrimination or the lack of sense of belonging for GMs is socially constructed. It is a social construct based on reproduced hegemonies and counter-hegemonies that depict certain units of social life, practices, religious rituals and beliefs as homogenous, patriarchal and subservient (Tagesschau, 2018a). Therefore, these 
structures, which are institutionalised or entrenched deeply in every relation, make it hard to break away from the present norm.

In relation to this social order, this study examines homosexuality in Islam, with variants of religious and cultural homophobias as they influence the dynamics of outgroup GMs. The intersectionality and cultural hegemony of sexuality and religion are crucial to the study. Islam's perceptions of homosexuality as a taboo, or not haram, an unholy theme or an area of debate are a one-way discourse - a path of total rejection or non-existence. This is emphasised by the application of sacred texts informing the heterosexual requirements of having a family and the traditionalist social order between men and women, which has been and will remain the status quo or dominant social norm, until queer rights become of public discourse.

This shift from the traditional way of perceiving gender roles is prevalent in the Western world. However, it could be argued that Muslims living in Western countries have their own opinions about GMs and their acceptability in Islam or practice of the religion. The historical and discursive comprehension of the social order in which sex and sexuality are sanctioned between a man and a woman (heterosexual married couples) sustains the social order. Homosexuality is seen as a taboo and the story of Lot, which appears in the Bible and in the Quran, is usually used as explicit evidence of the condemnation of homosexuality in religion and as a warning against provoking the wrath of the divine (Tagesschau, 2018a).

In reaction to the power and dominance displayed by Islamic clerics in interpreting sacred texts, Kugle (2010) posits that, for any progressive efforts towards redefining Islam in the modern world to succeed, Islamic clerics have to adopt liberal attitudes and non-patriarchal means in recreating an atmosphere where the sacred text and its followers are not seen as enemies or terrorists. This notion is strengthened by Yip (2008), who points to GMs being perceived as a Western disease, which explains the notion of heterosexual Muslims regarding GMs as perverse or culturally defiant and unholy (nicht Halal).

Based on the foregoing, homophobia is the result of repression, rejection and outright exclusion from a group. In a similar reasoning, Rahman (2014) posits that homophobia needs to be comprehended from the prism of Western Islamophobia, not necessarily because of religious beliefs or doctrines. Instead, other variables - such as societal structures, education, logical reasoning and some sense of Western exceptionalism - are involved. Western exceptionalism connotes the ability to think, perceive and behave according to accepted norms of Western countries. In this way, Muslims are framed as rigid, backward in political thought, and always leaning on superstitions or religious guidance rather than on rational and logical thinking.

Therefore, if the social wrong is to be addressed, the securitisation of labels such as Arab, the heterosexual cultural hegemony (rigid social construct of a family being made up of a heterosexual couple) and RC must be corrected. Disruptions of cultural hegemony and the production of counter-hegemonies should be attained before any restitution can be done to the social wrong or reframing of the social order.

\subsubsection{Stage 4: Possible way past the obstacles}

The dialectical relations between the social order and social wrong pave the way for divergent views. These views are informed by varying variables, including the varying levels of the socialisation process across groups, the level of Islamic securitisation in society, logical 
thinking in educational curricula, the pull or push factors of conservative-liberal cultural worldviews, reproduction of counter-hegemonies to withstand the negativity, discrimination or outcast label constructions to GMs and the influence on dogmatic theology through reformations. These variables apply to both the Western and non-Western societies involved in this discourse.

First, the social wrong that sees Arabs as a threat or a negative influence on Westernisation should be demystified and reframed, and the human attribute of weaponising or securitising perceived threats should be reconstructed. Numerous scholars view the othering of Arabs and the weaponisation or securitisation of perceived threats as a long-standing issue (Teo, 2000; Sides and Gross, 2013; Satti, 2015; Von Sikorski et al., 2017). Therefore, its origin is not mainly situated in the 9/11 attacks: the attacks merely brought it into the public sphere, where it remained one of the most framed and reproduced counter-hegemonies regarding a group. This era of the reproduction of counter-hegemonies regarding Islam, Arabs or Muslims may require a dialogue from both sides. From a political perspective, a neoclassical realist perceives the world as anarchic; yet cooperation between enemies and friends are deemed necessary to attain relative material power, although such arguments favour Western countries, which own the highest degree of relative material power in global politics.

However, it is the issue of dominance and cultural hegemony that is of relevance in this study. If, for example, the media and power wielders from Western countries refrain from painting a holistic picture of Muslims as threats or terrorists, then it may be possible to banish policies and inequalities shaped towards the 'other'. However, such efforts are futile if other actors affected by such framing, cultural hegemony or counter-hegemonies production and reproduction are not ready to undergo reforms. By reforms, I mean cooperation with Western authorities in dealing with terrorism or granting equal rights to GMs. The spread and diffusion of liberal values are crucial in disrupting the social order in the Middle East (Tagesschau, 2017; Tagesschau, 2018b).

Another point of relevance is the reformation of dogmatic theologies. Religion and cultures are meant to be dynamic and even the most conservative dogmas or practices are bound to face extinction or limited observance at some point. According to the report and debate on Tagesschau (2018a, 2018b), Islamic clerics hold great power and dominance over their followers. A bid to deconstruct GM's excommunication or isolation should, therefore, start with engaging Islamic clerics and RC. The latter stems from power and authority derived from sole interpretation or giving meaning to sacred texts. As evidenced by the report in Tagesschau (2018b), RC alongside interpretive power given to Islamic clerics make it difficult to correct social wrongs or the social order. As gatekeepers of sacred texts, a liberal worldview of sexuality and gender roles is crucial for reforming Islam.

As discussed earlier, the role of cultural hybridity through hybridised Arabs may also lead to the liberalisation of theological dogmas. The more liberal Islam clerics there are, the easier it would become to influence discourses on and perspectives of homosexuality or homophobia. 


\section{Conclusion}

To summarise, the cultural hegemony-fuelled nature of RC and homophobia has been clearly depicted as a social construct with social agents; particularly institutional gatekeepers and followers sustaining and reinforcing the status quo.

Over the past decades, different types of arguments have been presented in which RC is fostered by patriarchy and cultural hegemony or the reproduction of such dominant hegemonies. Another argument is that the social wrong is represented by the Western label or construct of Arabs. Such a construct of the other presents a social wrong upon which the social order is sustained. However, counter-hegemony substitutes flowing from the isolated class may result in a discourse. This discourse is said to bring together social agents - i.e. the gatekeepers of RC, hybridised Arabs, Western power wielders and institutions, conservative Muslims and reform-oriented clerics. In summary, any effort towards dialogue or addressing the social wrong should reflect the social agents and their grievances.

Despite its isolationism and nicht haram classification by the conservatives, framing GMs in Germany is objectified as a cultural failure. GMs are, therefore, a creation of structural and discursive isolationism within the superstructure. As such, any instance of discursive practice in relation to RC can be interpreted in terms of relationships of existing orders or discourse, based on power relations between agent and principal dictated by preferences such as status and class.

This article also highlights the struggles and challenges faced by GMs in reconciling their sexuality and their religious identity. It is hoped that the findings of this article would facilitate further ethnographic or qualitative research into the identity of GM in European countries.

\section{Keywords}

religious correctness; GMs; GMs in Germany; cultural hegemony; critical discourse analysis; hegemonic masculinity; Islamic hegemonic masculinity

\section{Reference list}

Abdel-Raheem, A. (2019), "Moral Metaphor and Gender in Arab Visual Culture: Debunking Western Myths", Social Semiotics, April 2019: 1-28. Available online at https://doi.org/10.1080/10350330.2019.1604991 (last accessed: May 15, 2020).

Agbedejobi, P. (2017), "Challenging Online Radicalisation: A Refutation of CounterRadicalisation Strategies, Counter-Narratives and a New Approach", SSRN, https://doi.org/10.2139/ssrn.2931179 (last accessed: May 15, 2020).

Akachar, S. (2015), "Stuck between Islamophobia and Homophobia: Applying Intersectionality to Understand the Position of Gay Muslim Identities in the Netherlands", Journal of Diversity and Gender Studies, 2 (1-2): 173-187.

Aly, R.M.K. (2015), Becoming Arab in London, London: Pluto Press.

BBC News (2018), Saudi Arabia Issues First Driving Licences to Women. BBC News. Available online at https://www.bbc.com/news/world-middle-east-44367981 (last accessed: May $15,2020)$. 
Connell, R.W., and Messerschmidt, J.W. (2005), "Hegemonic Masculinity: Rethinking the Concept", Gender \& Society, 19 (6): 829-859.

Das Erste Mediathek (2018), Imamin Seyran Ates will freiwillige Abgabe statt Moschee-Steuer. Available online at http://mediathek.daserste.de/Morgenmagazin/Imamin-Seyran-Ateswill-freiwillige-Abga/Video?bcastId=435054\&documentId=58922386 (last accessed: May $15,2020)$.

De Sondhy, A. (2014), The Crisis of Islamic Masculinities, London: Bloomsbury.

Delgado, R. (2001), "Two Ways to Think about Race: Reflections on the Id, the Ego and Other Reformist Theories of Equal Protection", Georgetown Law Journal, 89: 2279-2296.

Eco, U. (1976), Theory of Semiotics, Bloomington (IN): Indiana University Press.

El-Tayeb, F. (2012), “'Gays Who Cannot Properly Be Gay': Queer Muslims in the Neoliberal European City", European Journal of Women's Studies, 19 (1): 79-95. Available online at https://doi.org/10.1177\%2F1350506811426388 (last accessed: May 15, 2020).

Eroukhmanoff, C. (2018), Securitisation Theory: An Introduction. E-International Relations Students. Available online at https://www.e-ir.info/2018/01/14/securitisation-theory-anintroduction/ (last accessed: May 15, 2020).

Ewing, K.P. (2008), Stolen Honor: Stigmatizing Muslim Men in Berlin, Stanford (CA): Stanford University Press.

Fairclough, N. (2010), Critical Discourse Analysis: The Critical Study of Language (2nd edn.), Edinburgh: Pearson Education.

Forgacs, D. (1988), The Gramsci Reader: Selected writings, 1916-1935, New York (NY): New York University Press.

Ganzevoort, R.R, Van der Laan, M., and Olsman, E. (2011), “Growing up Gay and Religious: Conflict, Dialogue and Religious Identity Strategies", Mental Health, Religion and Culture, 14 (3): 209-222.

Garlick, S. (2016), The Nature of Masculinity, Vancouver: UBC Press.

Hegarty, P. (2019), “How Do We 'Other'”, The Psychologist, 32: 48-51.

Hermans, P. (2006), "Ethnic Identities of Moroccans in Belgium and the Netherlands", in L. Romanucci-Ross, G.A. De Vos and T. Tsuda (eds), Ethnic Identity (4 ${ }^{\text {th }}$ edn.), pp. 189-207, Lanham: Altamira Press.

Inhorn, M.C. (2012), The New Arab Man, Princeton: Princeton University Press.

Jewkes R., and Morrell, R. (2012), “Sexuality and the Limits of Agency among South African Teenage Women: Theorising Femininities and their Connections to HIV Risk Practices", Social Science \& Medicine, 74 (11): 1729-1737. Available online at https://www.ncbi.nlm.nih.gov/pubmed/21696874 (last accessed: May 15, 2020).

Koopmans, R. (2004), “Religious Fundamentalism and Hostility against Out-groups: A Comparison of Muslims and Christians in Western Europe", Journal of Ethnic and Migration Studies, 41 (1): 33-57.

Kugle, S. (2010), Islam and Homosexuality, Oxford: One World. 
Lears, J. (1985), “The Concept of Cultural Hegemony: Problems and Possibilities", The American Historical Review, 90 (3): 567-593. Available online at https://www.jstor.org/stable/1860957 (last accessed: May 15, 2020).

Mayeda, D.T., and Vijaykumar, R. (2016), "A Review of the Literature on Honor-Based Violence", Sociology Compass, 10 (5): 353-363.

McLellan, J. (2017), "Lesbians, Gay Men and the Production of Scale in East Germany", Cultural and Social History, 14 (1): 89-105.

Mechoulan, S. (2018), "The Case against the Face-Veil: A European Perspective", International Journal of Constitutional Law, 16 (4): 1267-1292.

Miller, J.A. (2018), Turkish Guest Workers in Germany: Hidden Lives and Contested Borders, 1960 1980s, Toronto: University of Toronto Press.

Mullet, D.R. (2018), "A General Critical Discourse Analysis Framework for Educational Research", Journal of Advanced Academics, 29 (2): 116-142.

Noble, G., and Tabar, P. (2002), “On Being Lebanese-Australian: Hybridity, Essentialism and Strategy among Arabic-Speaking Youth", in H. Ghassan (ed.), Arab-Australians: Citizenship and Belonging Today, pp. 128-144, Melbourne: Melbourne University Press.

Partridge, D.J. (2012), Hypersexuality and Headscarves: Race, Sex and Citizenship in the New Germany, Bloomington (IN): Indiana University Press.

The Quran, Surah Al-A'raf 7:81. Available online at https:/quran.com/7/81 (last accessed: May $15,2020)$.

Rahman, M. (2014), Homosexualities, Muslim Cultures and Modernity, Basingstoke: Palgrave Macmillan.

Rehman, J., and Polymenopolou, E. (2013), "Is Green a Part of the Rainbow? Sharia, Homosexuality and LGBT Rights in the Muslim World", Fordham International Law Journal, $\quad 37 \quad(1)$ : 1-52. Available online at https://ir.lawnet.fordham.edu/cgi/viewcontent.cgi?article=2322\&context=ilj (last accessed: May 15, 2020).

Reporter (2016), "Homophobie im Islam: Kann Man Moslem und Schwul sein?", YouTube, June 22, 2016. Available online at https://www.youtube.com/watch?v=wZSeb9_0tpk (last accessed: May 15, 2020).

Satti, M. (2015), "Framing the IS on Al Jazeera English and the BBC Websites", Journal of Arab $\mathcal{E}$ Muslim Media Research, 8 (1): 37-53.

Shaheem, S.I. (2014), Emirati Students in the UK: Cultural Identity Transformation, Unpublished Doctoral Dissertation, University of East London.

Shier, A., and Shor, E. (2016), “'Shades of Foreign Evil': 'Honour Killings' and 'Family Murders' in the Canadian Press", Violence against Women, 22 (10): 1163-1188.

Sides, J., and Gross, K. (2013), "Stereotypes of Muslims and Support for the War on Terror", The Journal of Politics, 75 (3): 583-598.

Siraj, A. (2010), "Because I'm the Man! I'm the Head: British Married Muslims and the Patriarchal Family Structure", Contemporary Islam: Dynamics of Muslim Life, 4 (2): 195214. 
Tagesschau (2017), “Der Moscheereport: die Dar-as-Salam-Moschee”, YouTube, April 24, 2017. Available online at https://www.youtube.com/watch?v=X-qfjQWjSOI (last accessed: May 15, 2020).

Tagesschau (2018a), "Moscheereport: Islam und Homosexulität", YouTube, April 28, 2018. Available online at https://www.youtube.com/watch?v=I0dRCzs1hvs (last accessed: May 15, 2020).

Tagesschau (2018b) "Moscheereport: Islam und Frauen", YouTube, September 6, 2018. Available online at https://www.youtube.com/watch?v=cJ6nJqs1iEM (last accessed: May 15, 2020).

Teo, P. (2000), "Racism in the News: A Critical Discourse Analysis of News Reporting in Two Australian Newspapers", Discourse \& Society, 11 (1): 7-49.

Van Leeuwen, T., and Jewitt, C. (2001), Handbooks of Visual Analysis, SAGE.

Von Sikorski, C., Schmuck, D., Matthes, J., and Binder, A. (2017), “Muslims Are Not Terrorist: Islamic State Coverage, Journalistic Differentiation between Terrorism and Islam, Fear Reactions and Attitudes Towards Muslims", Mass Communication and Society, 20 (6): 825848.

Waller, L.G. (2006), “Introducing Fairclough's Critical Discourse Analysis Methodology for Analysing Caribbean Social Problems: Going beyond Systems, Resources, Social Action, Social Practices and Forces of Structure or Lack thereof as Units of Analysis", Journal of Diplomatic Language, 3 (1). Available online at https://papers.ssrn.com/sol3/papers.cfm?abstract_id=912329 (last accessed: May 15, 2020).

Yip, A.K.T. (2008), “The Quest for Intimate/Sexual Citizenship: Lived Experiences of Lesbian and Bisexual Muslim Women", Contemporary Islam, 2 (2): 99-117.

Zulkffli, M.A, and Ab Rashid, R. (2016), A Discursive Psychological Analysis of Islamic Sermons on Homosexuality, International Journal of Applied Linguistics and English Literature, 5 (6): 190-198.

Zulkffli, M.A., and Ab Rashid, R. (2019), Discursive Strategies Employed by Homosexual Malaysian Muslim Men in Talking about Homosexuality in Islam, Discourse \& Society, 30 (3): 307-320.

\section{Appendix}

\section{EXTRACT 1: TAGESSCHAU 2018a}

Opening statement in German: Gehört der Islam zu Deutschland oder welchen Islam gehört zu Deutschland? Darüber wird wieder einmal politisch diskurtiert. Hintergrund dort ist die Frage wie: Islam und unsere freiheitliche Gesellschaft zusammenpassen etwa bei Thema Homosexualität....

Opening Statement Translation: Does Islam belong to Germany or which Islam belongs to Germany? This is the focus of political discussion. In the background is the question: 
how does Islam conform to a liberal community in terms of the theme of homosexuality?

\subsection{0-1.12 $\mathrm{min}$}

Constantin Schreiber (CS): How are gay men perceived in Islam?

Ibrahim: When you are gay you bring shame to your family and community. They do think they have failed as a parent in terms of your upbringing. Second point is building your case against the divine (Allah). Thirdly, you are sick and must undergo therapy or treatment.

\subsection{1-1.48 min}

Ibrahim: When you are gay- you are a second-class citizen and treated without respect. You would always be a source of discrimination, violence and ....

\subsection{8-3.45 $\mathrm{min}$}

(CS): what happens when you come out as gay?

Ibrahim: In Lebanon, I lived a life of constant discrimination, threats and violence.

Narration of CS-attitude to gay people in Lebanon: the point of renouncing my religion and departing Lebanon came when I had a fake date through an app- which ended up being a planned ambush by Islamist who took the role of the divine during Ramadan, to judge and punish me. They threw me out of the third floor of a building. I survived been thrown out of the third storey building.

After 10 months in bed, I could walk again and left Lebanon through the Balkan route in search of a haven elsewhere in Europe. Today I have little or no contact with my family. My family in Lebanon tried to heal me, my sexuality is treated as a sickness. They took me to an Imam. My parents were more concerned about what the community would say about them. Consequently, my sisters cannot marry or find suitors, because the prospective suitors think that their offsprings might also turn out to be gay.

\section{EXTRACT 1.1: TAGESSCHAU 2018A}

\section{$3.53-4.37 \mathrm{~min}$}

(CS): Do similar opinions also exist in the Islamic community in Germany?

Ahmad Mansour (AM): It is a topic of taboo, which implies there would be no conversation or dialogue about it. And when cases emanate due to been discovered in social circles or the parents get a hint of it. Then the use of violence takes a great role or excommunication and isolation from the community and family is taken as a deterrence. That said, been gay might lead to the suppression of sexuality or secretly hide their identity.

\section{EXTRACT 1.2: TAGESSCHAU 2018A}

\subsection{9-9.14 min}


CS: what does the Quran say about homosexuality?

Professor Adnan Aslan (AA): Many colleagues and Imams theological interpretation come from Sura 11 or 15 . When you compare the context, text of both stories, you see that they have different representations and interpretations within the same book. This implies that one cannot interpret such text from a historical fact.

CS: was Islam 100BC liberal in terms of homosexuality?

AA: in terms of practice and traditional conventions related to Prophet Muhammed, Muslims then were quite liberal in relation to present day Muslims. The relationship with homosexuality in present day is illiberal. That explains the reason why Islam in $11^{\text {th }}$ and $12^{\text {th }}$ century was progressive and while modern day Islam is illiberal.

CS: when we talk in terms of the present-day Islamic practice, do we have a liberal theological perspective in relation to the theme of homosexuality?

AA: this liberal theology is most likely to emerge from Europe due to its embrace of liberal values. When a society or community does not promote freedom, it is difficult for liberal theology to develop. That is the reason why in Europe, such liberal theology is been promoted, with a European blend which may constitute a form of learning curve and further diffusion potential to other Islamic countries.

\section{EXTRACT 1.3: TAGESSCHAU 2018A}

\subsection{8-15.24 min}

CS: Is homosexuality a sin?

Said Ahmad Arif (SAA): In theological terms, yes, it is a sin. There are other religions that see it as a sin also.

CS: Do you have homosexual members in your mosque or do you ignore the existence of such?

SAA: until now, no one has come up to identify as homosexual, we do not ask after our members sexual orientation. That is why I cannot know if any exist. But nobody has come up to me that he/she is homosexual.

CS: what happens if anyone comes forth?

SAA: if someone acknowledges that he/she is queer, the responsibility falls on our spiritual leader to counsel the person on whether he/she can keep visiting the mosque. However, out of love for the person, it would be counselled that homosexuality does not belong to Islam.

CS: Does that mean if you are homosexual- you cannot be a formal member of the mosque? One can visit or pray in the mosque but can never be a member?

SAA: In formal terms, it implies if someone wants to be a member, the membership declaration form by the mosque is together entrenched with the teachings of Islam, how to relate with one another and the homogeneity of the institution of marriage, family which is between a man and woman. 
CS: So basically, such individuals have a choice to live in freedom in Germany or choose not to exercise their freedom of sexuality?

SAA: Of course, such individuals have a choice to make, either to openly live in freedom in relation to their sexuality or to be a member of the mosque. This is a contradiction. Therefore, one must decide what path he/she wants to follow.

CS: Is this not a parallel/simultaneous community represented by the depiction- what is permissible out there is not permissible in the mosque?

SAA: yes, ok outside there, we have different religious and non-religious bodies and individuals against such sexuality. The most important thought here is that each parties should respect the tradition, beliefs and practices of others. As a body, we do not push our beliefs or practices on others, we expect that from others too. We expect the respect of private spheres.

CS: here in Germany, there has been a shout for church reform to match up the developments and changes in the society. Should there be such reform for Islam, do you feel the pressure from the public or society and how can one navigate such pressure?

SAA: of course, we do feel the pressure from the society. In relation to Islam, the pressure is also there, but one has a certain expectation, for instance, this is how a Muslim should look like or fit the perfect profile or picture painted by Islam. We are ready to open a communication channel with our members, but this does not mean we must compromise our religious principles or ideology. Thus, our religious principles are important, and we encourage integration to the larger German community.

CS: Do I clearly understand it that Islam does not need a reform especially in relation to homosexuality as a sin should be sustained?

SAA: this depends on what you understand to be reform. For me reform implies going back to the root or traditional basis, teachings of my religion- a religion which is peaceful and human friendly. For us, we are interested in preserving the teachings of the religion, but also, we want to comply with the laws of the land and have a freedom of opinion in relation to the topic of homosexuality.

SAA: I hope I have not infringed on any law?

CS: no, but you restrict freedom.

SAA: whose freedom?

CS: the freedom of those who openly want to live as homosexuals, which is guaranteed in Germany but not by the mosque.

SAA: but he/she can decide on which path to follow or what to do with his life.

CS: In relation to which religion?

SAA: He can see himself/herself as a Muslim, he can be known by the congregation or members. But formal membership or membership admission to the mosque is a contradiction. For the person, how can he live with such a contradiction?

CS: am I Islamophobic for asking you such questions?

SAA: No, you can ask me such questions. Important is that you hold a civilised and respectable conversation or exchange. 


\section{EXTRACT 2: REPORTER 2016}

\subsection{4-2.04 min}

German Interviewer: ... Es klingt als hatten Muslimgesellschaft ein echtes homophobie Problem.Ich frage Mohammad Mokassa (MM) Islam Wissenschafler der StiftungWeltethos ob das stimmt?

Interviewer: It sounds as if the Muslim society has a real homophobia Problem. I ask Mohammed Mokassa an Islamic scientist from the foundation Weltethos if this is correct?

\section{EXTRACT 2.1:}

\section{$2.06-2.58 \mathrm{~min}$}

MM German response: in gegenwärtige standpunkt, hat in der Muslmische gesellschaft ein Homosexualler keinen Platz. Wer homosexuell ist, dem wird sein Muslim sein abgesprochen. Er gilt als verstoßener. In der Regel trenn die Familie Kontakt zu dieser Person und wenn es offentliche bekannt ist, dass man homosexuell ist. kann es wieder ihn passieren, dass er angespockt, beschimpft werden in der öffentlichkeit. Das bis hin ihm gewalt in der öffentlichkeit begegnet.

Aber da gibt noch eine Zweite ebene seites des Rechtes. Wir haben 19 muslismische Ländern in den Homosexualität keine Strafe steht. Länder wie Bosnia-Herzegovina, der Turkei, der Iraq, Jordanien. Wir haben aber auch, das muss auch gesagt werden, 21 Ländern, in den da Homosexualität haftstrafe steht- Ägypter und Marroko und 7 Landern in den auch Homosexualität der Todesstrafe steht.

MM English: In terms of modern-day position, Homosexuality has no place in the Muslim society. Whoever is homosexual, his right to be called Muslim is denied. He is seen as a castaway or outcast. It is a norm that the family cuts any relations with such person and when it is publicly known that he is homosexual. It can happen that you are spitted on in public or abused in public. It is possible that such a person faces violence in the public. But there is another second position to this, which is a legal perspective. We have 19 Muslim countries in which no punishment nor penalty exist for homosexuals. Countries such as Bosnia-Herzegovina, Turkey, Iraq, Jordan. We also have another 21 countries where Homosexuality is a punishable offence like Egypt and Morocco and another 7 countries where homosexuality is punishable by death.

\section{EXTRACT 2.2:}

\section{$3.54-4.20 \mathrm{~min}$}

Interviewer German: Sind Homosexuelle deutsche Muslimische gemeinden her akzeptiert? (Is homosexuality in the German Muslim community accepted?) 
MM response German: wir haben in der deutsche Muslimische community in Deutschland, ob es sich jetzt um Akademiker oder nicht Akademiker handelt eine ebenfalls eine höhe Homophobie. eine Ablehnung von Homosexuell und mann muss es erhlich zugeben nur in wenigen Gemeinschaften können Homesexuelle Muslime auftreten und teil der Gemeinschaft sein. Aber überwiegend auch hier Ablehnung.

MM English translation: We do have in the Muslim community in Germany- whether it is from academics or non-academics, likewise a high level of homophobia. A rejection of homosexuality and this one must honestly concede that it is only in relative few Muslim community that Homosexuals are welcome or can take part in the community. But it is highly rejected.

\section{EXTRACT 2.3:}

\section{$4.20-4.51 \mathrm{~min}$}

Interviewer German: war das in der Muslimische Gemeinschaft schon immer so? gab es Zeiten in den Homosexualität her akzerptiert wurde?

English: was this always so in the Muslim community? Or was there a time when homosexuality was accepted?

MM German response: In Muslimische mittelalter, hat sich eine Kultur der Duldung. Duldung als Unterstufe der Toleranz heraus entwickelt. Man hat homosexualität geduldet so lange sie eben die homosexualität nicht in der öfffentliche raum presentiert oder rein transportiert haben. Sondern eben verborgene zuhause in Private ausgelebt habe. Es war eine Kultur- ,'dont ask dont tell'

MM English: In Medieval Muslim era, there was a culture of tolerance. Tolerance developed at an elementary level. Homosexuality was tolerated so long as it remains hidden from public sphere. It was suppressed in public sphere, only allowed within private lives. It was a culture of don't ask don't tell.

\section{EXTRACT 2.4:}

\subsection{1-5.48 min}

German Interviewer: warum ist das nicht mehr so? wie kam es zu Sinn des wandels?

English: why is it that no longer so (reference to tolerance in medieval era)? How did the purpose change?

MM German: Das liegt an zwei Punkten, zu einem, eben das wir in der religiose Texte heute am schwarz und weiß denken, der interpretation suchen, statt der grau zone und zum andern hat homosexualität verändert. In mittelalter war homosexualität eine Handlung, keine Identität. Bedenken Sie der Begriff homosexualität haben erstmal 886 auf. auch inhaltliche als eine Identität und nun in der moderne treten Menschen auf und wollen in der öffenlichkeit das homosexuelle annerkant werden. Das verstoßt gegen den Konsens in diese Muslimische gesellschaft. Über Jahr hundert hin weg bestand hatte und wird eben als ein affront gesehen. Wir haben also gegenwärtig in 
der Muslimische Welt, mit einem Kulturkampf was sie sexuelle Selbstbestimmung des individuums zu tun.

English: This depends on two points, on the one hand, religious texts today are perceived in black and white. The interpretation of text does not examine the context of the text. On the other hand, scope and representation of homosexuality has changed. In the medieval period, homosexuality was an act not an identity. Think of homosexuality in the medieval period and now as an identity in which people want their sexuality to be recognised in public. This contradicts the consent of the Muslim society, which, over hundreds of years, has buried homosexuality in the past. Homosexuality stands as an affront to Islam. We therefore today in the Muslim world have a cultural clash which has to deal with the sexual self-determination of the individual. 